This item was submitted to Loughborough's Research Repository by the author.

Items in Figshare are protected by copyright, with all rights reserved, unless otherwise indicated.

\title{
The heart of a Gopi: Raihana Tyabji's bhakti devotionalism as self-
}

\section{representation?}

PLEASE CITE THE PUBLISHED VERSION

PUBLISHER

(C) Cambridge University Press

VERSION

AM (Accepted Manuscript)

LICENCE

CC BY-NC-ND 4.0

\section{REPOSITORY RECORD}

Lambert-Hurley, Siobhan. 2019. "The Heart of a Gopi: Raihana Tyabji's Bhakti Devotionalism as Selfrepresentation?”. figshare. https://hdl.handle.net/2134/12285. 


\title{
Modern Asian Studies
}

http://journals.cambridge.org/ASS

Additional services for Modern Asian Studies:

Email alerts: $\underline{\text { Click here }}$

Subscriptions: $\underline{\text { Click here }}$

Commercial reprints: $\underline{\text { Click here }}$

Terms of use : $\underline{\text { Click here }}$

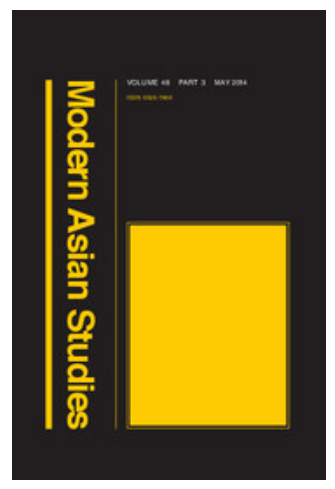

\section{The Heart of a Gopi: Raihana Tyabji's Bhakti Devotionalism as Self-Representation}

\author{
SIOBHAN LAMBERT-HURLEY \\ Modern Asian Studies / Volume 48 / Issue 03 / May 2014, pp 569 - 595
}

DOI: 10.1017/S0026749X12000704, Published online: 09 July 2013

Link to this article: http://journals.cambridge.org/abstract S0026749X12000704

How to cite this article:

SIOBHAN LAMBERT-HURLEY (2014). The Heart of a Gopi: Raihana Tyabji's Bhakti Devotionalism as Self-Representation . Modern Asian Studies, 48, pp 569-595 doi:10.1017/S0026749X12000704

Request Permissions : $\underline{\text { Click here }}$ 


\title{
The Heart of a Gopi: Raihana Tyabji's Bhakti Devotionalism as Self-Representation*
}

\author{
SIOBHAN LAMBERT-HURLEY
}

\author{
Loughborough University, UK \\ Email: S.T.Lambert-Hurley@lboro.ac.uk
}

Raihana Tyabji is best known in history, not for her writing or even her singing, but as a devotee of Gandhi. Yet in 1924 this at least nominally Muslim woman composed a small book of bhakti devotionalism that has continued to garner popular interest right into the twenty-first century. She gave it the evocative title, The Heart of a Gopi, on the basis that what had been revealed to her was the very 'soul', the inner self, of the gopi and, through that, an understanding of Lord Krishna himself. This paper considers the question of how far this piece of bhakti devotionalism may be read as a kind of personal narrative, an evocation of the self. Does the referencing of an established narrative tradition give the author's feelings and experiences, especially as a Muslim woman devoted to Krishna at a time of increasing religious rigidity and growing communal strife, a kind of validity not achievable otherwise? And, if so, how do we separate out the author's 'self' from the literary conventions-in this case, the gopi tradition- that structure the story? In the tradition of Islamic life-writing, can the gap between the miraculous and the mundane be breached in order to understand the mystical experience charted here as a kind of autobiography? Even from the rationalist's perspective, should not the life of the imagination still be considered part of the life?

* Earlier drafts of this paper were presented at the panel, 'Speaking of the Self? Women and Self Representation in South Asia', at the European Conference on Modern South Asian Studies in Bonn, Germany in July 2010; and at the South Asia Studies Seminar at the University of Leeds in March 2011 . My thanks to the participants, and especially to my co-convenor in Bonn, Anshu Malhotra, for their extremely useful comments on these occasions and after. I am also grateful to Anand Vivek Taneja and Sunil Sharma for their suggestions. More generally, this paper has benefited from lively discussions held in connection with the international research network, 'Women's Autobiography in Islamic Societies' [http://www.waiis.org, accessed 14 October 2012]. 


\section{Introduction}

In 1924, a young woman called Raihana Tyabji 'suddenly felt', in her own words, 'a tremendous, an irresistible urge to write'. She sat down at her desk 'with sheets of foolscap and poised pen' and, over the next three days, poured out the story of Sharmila, a gopi, or milkmaid, enraptured by Krishna in his guise as the cowherd at Vrindavan. At the time, she understood this narrative to be, as she called it, a 'Fragment of a Gopi's Diary'. But, in time, she recognized that what had been revealed to her-for she understood herself to be 'possessed' at the time of writing — was the very 'soul', the inner self, of the gopi and, through that, an understanding of Lord Krishna himself. Hence, when her tale was eventually published in 1936, she gave it the evocative title, The Heart of a Gopi. ${ }^{1}$ Subsequently, her little book went into several reprints and editions in its original English (1941, 1953, 1971), while also being translated into several European languages, including French (1938), German (1977) and Dutch (1995). ${ }^{2}$ Excerpts from the French edition, $L$ 'Âme d'une Gopi, were even crafted into songs sung by Raihana herself, certainly in a recording for the American composer and choral singer, Catherine Urner $(1941-1942) .{ }^{3}$ Today, the book is still available and often quoted in a most diverse set of contexts-from academic studies of Hinduism and websites on spirituality to a blog on 'Godwriting' and the 'official George Harrison messageboard'. ${ }^{4}$ Most recently, it has even been made into a musical that takes dialogue directly from the original text. ${ }^{5}$

${ }^{1}$ Raihana Tyabji, The Heart of a Gopi (Poona: Miss R. Tyabji, n.d.). The quotes here come from pp. v-vi.

${ }^{2}$ Raihana Tyabji, The Heart of a Gopi (Bombay: Vora, 1941; n.p.: n.d., 1953; Delhi: East West Publication, 1971); L'Ame d'une Gopi, trans. Lizelle Reymond (Frameries, Belgium: Union des Imprimeries, 1935); Das Herz einer Gopi (Darmstadt: Synergia/Syntropia, 1977); Het hart van een Gopi (Rotterdam: Synthese Uitgeverij, 1995).

${ }_{3}^{3}$ See Inventory of the Catherine Murphy Urner Collection, [ca. I9Io-ca. I942], Music Library, University of California, Berkeley: http://www.oac.cdlib.org/data/

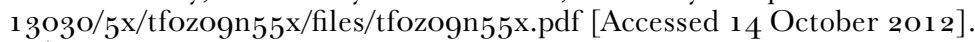

${ }_{4} \mathrm{See}$, as examples, René Guénon, Studies in Hinduism, trans. Henry D. Fohr (Hillsdale New York: Sophia Perennis, 2001), pp. 194-195; Lord Krishna: http://www. ramdasstapes.org/krishna.htm [Accessed 14 October 2012]; The heart of a gopi: http://board.georgeharrison.com/viewtopic.php?q=board/viewtopic.php\&f $=7 \& \mathrm{t}=$ 4111 [Accessed 14 October 2012]; and Heart of a Gopi: http://www.blogcatalog. $\mathrm{com} / \mathrm{blog} /$ godwriting [Accessed 14 October 2012].

5 'The Heart of a Gopi-The Screenplay' [http://heartoagopi.org', accessed 10 December 2009]. (C) 2008-2010. 
The ongoing interest in The Heart of a Gopi-right into the twenty-first century-points to the success of this at least nominally Muslim woman in having her spiritual writings accepted within other religious traditions. With this achievement, we are reminded of other individuals and communities in South Asian culture and history that have inhabited the shifting ground between faith groups and thus rejected an exclusively 'Hindu' or 'Muslim' (or, indeed, 'Sikh' or 'Christian') paradigm. ${ }^{6}$ Perhaps the most popular of these liminal figures would be the fifteenth century poet and saint, Kabir. In mocking both pandit and mullah, he rejected ritualistic forms of religion as practiced in the mandir or the masjid, the temple or the mosque. It is this trope of resistance to organized Hinduism or Islam that makes him so important not only as a foundational figure within certain Sikh sects, but also in the Bhakti movement with its emphasis on spontaneous expressions of devotion, as directed at Rama or, especially, Krishna. ${ }^{7}$ One may also think of Sufi poets, like Bulleh Shah in eighteenth century Punjab, who, to the extent of none before, absorbed 'Hindu' elements, including Krishnaite images, into his 'Muslim' devotional poetry. ${ }^{8}$ Perhaps the best model here though, in that his 'elegant and impassioned verses in praise of Krishna' did not just borrow 'Hindu' imagery, but, in the words of Rupert Snell, demonstrated a 'complete commitment to Vaishnava sentiments', is the sixteenth century poet Raskhan. Like Raihana, this Muslim Pathan's 'trascendental persona'

${ }^{6}$ Two studies of such liminal communities in a historical context are: DominiqueSila Khan, Crossing the Threshold: Understanding Religious Identities in South Asia (London: I.B. Tauris and Co, 2004); and Shail Mayaram, Resisting Regimes: Myth, Memory and the Shaping of a Muslim Identity (New York: Oxford University Press, 1997). For a more popular, contemporary study, though with a strong historical element, see Yoginder Sikand, Shared Spaces: Exploring Traditions of Shared Faith in India (Delhi: Penguin, 2003).

${ }^{7}$ On Kabir and the Bhakti movement more generally, see John Stratton Hawley, Three Bhakti Voices: Mirabai, Surdas and Kabir in Their Time and Ours (New York: Oxford University Press, 2005).

${ }^{8}$ My coverage of Bulleh Shah here draws on Anshu Malhotra, 'Telling her Tale? Unravelling a life in conflict in Peero's IK Sau Sath Käfian (one hundred and sixty kafis)', The Indian Economic and Social History Review 46:4 (2009), p. 572-573, but, for a more comprehensive discussion, see Denis Matringe, 'Krsnaite and Nath Elements in the Poetry of the Eighteenth Century Panjabi Sufi Bulhe Sah' in R. S. McGregor (ed.), Devotional Literature in South Asia (Cambridge: Cambridge University Press, 1992), pp. 190-206. On 'shared philosophical beliefs and imageries' between the Bhakti and Sufi movements more generally, see Bruce Lawrence, 'The Sant Movement and North Indian Sufis' in Karine Schomer and W. H. McLeod (eds), The Sants: Studies in a Devotional Tradition of India (Delhi: Motilal Banarsidass, 1987), pp. 359-373. 
was that of a gopi endowed with such 'urgent passion' that his devotion to Krishna is conceived as 'conversion'?

Yet The Heart of a Gopi is not just of interest as an example of 'crossing the threshold', to borrow the phrase of Dominique-Sila Khan. ${ }^{10} \mathrm{It}$ also attracts interest as part of a literary and historical project of theorizing the relationship between gender, history and the self. Historians of South Asia have been at the forefront of those scholars going beyond conventional autobiography to examine the diverse ways in which individuals-including those from marginalized groups and pre-modern societies-have found means for self-fashioning and selfrepresentation. ${ }^{11}$ To draw out women's conceptualizations of self has proved more difficult within the specific cultural conventions and constraints of a society that privileges the silencing of female voicesto the point that Gayatri Spivak has asserted that the South Asian woman has no real 'voice'. ${ }^{12}$ And yet, where the effort has been made for recovery, it has pointed to the creative ways in which women have been able to narrate their life stories, or at least aspects of them, by 'negotiating' with entrenched gender ideologies to manipulate the specific cultural resources at their command. ${ }^{13}$ As Anshu Malhotra writes of the recusant Peero's I6o Kafis, this may be a 'convoluted and metaphorical path' to 'unfold[ing] one's own drama', but it still represents 'careful self-fashioning' in a 'universe comprehended through emulation, allegory and allusion'. ${ }^{14}$

Raihana Tyabji left to history not a memoir per se, but, rather enigmatically, a few letters, some recordings, a couple of thin books in Hindi, plenty of memories and reminiscences, and The Heart of a Gopi. To be considered in this paper is how far this piece of bhakti devotionalism may still be read as a personal narrative, an evocation

${ }^{9}$ Rupert Snell, 'Raskhān the Neophyte: Hindu Perspectives on a Muslim Vishnava' in Christopher Shackle (ed.) Urdu and Muslim South Asia: Studies in Honour of Ralph Russell (Delhi: Oxford University Press, 1991), pp. 29-37. For particular quotes, see pp. 29, 32, 34. My thanks to Sunil Sharma for this reference.

10 Khan, Crossing the Threshold.

${ }^{11}$ As an example, see David Arnold and Stuart Blackburn (eds), Telling Lives in India: Biography, Autobiography, and Life History (Delhi: Permanent Black, 2004).

${ }^{12}$ See Gayatri Spivak, 'Subaltern Studies: Deconstructing Historiography' in Ranajit Guha (ed.), Subaltern Studies: Writings on South Asian History and Society IV (New Delhi: Oxford University Press, 1985), pp. 330-363.

${ }^{13}$ Deniz Kandiyoti, 'Bargaining with Patriarchy', Gender and Society 2 (1988), pp. $274^{-298 .}$

${ }^{14}$ Malhotra, 'Telling her Tale?', pp. 544-545, 566. 
of the self. A starting point will be to gain some insight into Raihana's personhood by piecing together some biographical information about her life from family papers, interviews, the national archive and her own writings. Her recourse to bhakti as a trope of the liminal self will then be considered. Does the referencing of a great tradition give the author's feelings and experiences, especially as a nominal Muslim devoted to Krishna at a time of increasingly religious rigidity and communal strife, a kind of validity not achievable otherwise? The third section considers the text itself within the context of the gopi tradition. Is it possible-and, if so, how-to separate out the author's 'self' from the literary conventions that structure the story? In conclusion, the paper will ask if, in the tradition of Islamic lifewriting, the gap between the miraculous and the mundane can be breached in order to understand the mystical experience charted here as a kind of autobiography? Even from the rationalist's perspective, should not the life of the imagination still be considered part of the life?

\section{Raihana's personhood}

So, who is Raihana Tyabji? As her surname may suggest, she was born into the prominent Tyabji clan that was at the forefront of Bombay's Sulaimani Bohra community in the late nineteenth and twentieth centuries. Her father, Abbas Tyabji (1853-1936), was the grandson of the clan's founder, Tyab Ali (also known as Tyabji Bhoymeeah), through his father, Shamsuddin. Though Abbas was first married to his elder paternal uncle Camruddin's daughter, Ashraf-un-Nissa (with whom he had two sons), upon her death he married Ameena Begum, eldest daughter of the Tyabji clan's perhaps most famous son (and Abbas's younger paternal uncle), Badruddin (1844-19o6). With his second wife, Abbas produced four children (one son and three daughters), including Raihana (1901-1975). The family was based, not in Bombay like most other Tyabjis, but instead in the princely state of Baroda in Gujarat, ruled in Raihana's youth by the larger-than-life figure of Maharaja Sayaji Rao III (1863-1939, ruled 1875-1939). In 1879 , the maharaja, or at least his dewan, was responsible for appointing the then young Abbas, who had fairly recently returned from studying law in London, to Baroda's judicial service. By 1885 , Abbas had risen to the top of this service as a judge of the Baroda high 
court, a position that he retained until his retirement in $1913 \cdot{ }^{15} \mathrm{In}$ Baroda, Ameena too distinguished herself, not just as a hostess and a companion to the maharani (including on a trip to Europe in 1894), but also as an educationalist. Specifically, she oversaw the Muslim girls' school established by the maharaja at her encouragement in the mid 189 os. ${ }^{16}$

According to Abbas's recent biographer, Ameena should also be attributed with involving her husband and children with India's preeminent nationalist leader, Mohandas Karamchand Gandhi, soon after his return from South Africa in 1915 . Seemingly, she had 'great respect and affection' for the Mahatma-to-be having known him since the early 1890 s when her esteemed father, Badruddin, himself a president of the Indian National Congress in 1887 , had befriended the unknown lawyer before he left Bombay for Natal. ${ }^{17}$ Abbas too had been a member of Congress from its establishment in $188_{5}$, even attending the historic sessions held in 1889, 1906 and 1907, but always, in his own words, as a representative of the 'Moderates' committed to achieving concessions for the Indian population by working with the British government. ${ }^{18}$ A first meeting with Gandhi at an elegant party in Bombay in 1915 did not change his views, instead leaving him 'not particularly impressed'. ${ }^{19}$ The following year, however, ties between Abbas's family and Gandhi were firmed up when Ameena arranged for her brother, Salman, to invite Gandhi and his wife, Kasturba, to dinner, before they all visited the couple at their own home the next day. ${ }^{20}$ Sometime later that year, Abbas' and Gandhi's budding friendship seems to have blossomed when both stayed with Ameena's youngest sister, Safia, and her husband, Jabir Ali, at their home in Tavoy in Burma. ${ }^{21}$ In time, Abbas-referred to within the context of the nationalist movement as the 'Grand Old Man of Gujarat'—was to

${ }^{15}$ On Abbas's judicial career, see Aparna Basu, Abbas Tyabji (New Delhi: National Book Trust, India, 2007), pp. 24-42.

${ }^{16}$ On this school, see Basu, Abbas, pp. 34-36. On Ameena Tyabji's experiences in Europe, I consulted a transcript of a speech delivered by her at the family ladies' club, Akdé Suraya, on 22 August 1904. It is kept in the private collection of Rafia Abdul Ali in Mumbai.

${ }^{17}$ Basu, Abbas, pp. 43-44.

${ }^{18}$ Ibid., pp. $5^{\text {O, }} 53$.

${ }^{19}$ Ibid., p. 43 .

${ }^{20}$ Ibid., p. 44 .

${ }^{21}$ Safia Jabir Ali, 'Manuscript Memoirs of Mrs Safia Jabir Ali', in Badruddin Tyabji Family Papers VI, Nehru Memorial Museum and Library, New Delhi. 
become one of Gandhi's most dedicated lieutenants, even leading the famous Dandi salt march after Gandhi's arrest and being jailed for his political activism. ${ }^{22}$

If the occasion was the same as the party referred to above, the teenage Raihana was rather more drawn to the saintly Gandhi on their first meeting than was her father. As she recalled in an interview with Ved Mehta at some point in the 1970s:

I caught a glimpse of him in the midst of silks and brocades, frills and sparkling jewels. He was dressed in a coarse khadi dhoti and looked like a small-time tailor who'd wandered in by mistake. I lost my heart to him. He became my father, my mother, my girlfriend, my boyfriend, my daughter, my son, my teacher, my guru. ${ }^{23}$

In subsequent weeks, the rising politician and the cosseted young girl sought one another out at a number of other parties in Bombay and then privately, quickly establishing what Raihana described as a 'very intimate' relationship that was to last until the Mahatma's tragic end. ${ }^{24}$ Their amity is evident in that his Collected Works contain over 8o epistles from Gandhi to Raihana over the 20-year period from 1927 to 1947-and these appear to be only a fraction of their original correspondence. Indeed, Gandhi's diary suggests that he actually wrote to her at least every couple of weeks and sometimes as often as twice a week, especially from prison. ${ }^{25}$ Unfortunately, we do not have Raihana's side of the exchange beyond a few extracts in published articles; as Gandhi explained to her in a letter from 1927, 'I destroy all your letters after replying, ${ }^{26}$ Still, one gets a good sense of their familiarity and fondness for one another in that Gandhi addressed

${ }^{22}$ On this, see Basu, Abbas, pp. 67-74.

${ }^{23}$ Quoted in Ved Mehta, Mahatma Gandhi and His Apostles (Harmondsworth, Middlesex: Penquin Books, 1976), p. 211 . For another account of their first meeting, see the interview with Raihana Tyabji in Usha Thakkar and Jayshree Mehta (eds), Understanding Gandhi: Gandhians in Conversation with Fred J Blum (Delhi: Sage, 201 1), p. $15^{8-160 .}$

${ }_{24}$ Thakkar and Mehta, Understanding Gandhi, p. 160.

${ }^{25}$ See, as an example, 'Diary, 1932', in Collected Works of Mahatma Gandhi Online: http://www.gandhiserve.org/cwmg/cwmg.html [Accessed 15 October 2012] [subsequently $C W M G O$ ]. From Gandhi's letters, we know too that, at the least, he began reading The Heart of a Gopi in its first incarnation as a 'Gopi's diary' before leaving it for the Bardoli satyagraha in 1928. Sadly, there is no record of his opinion other than that he considered it 'quite good news' to hear that it was to be first published in the mid-1930s. See letter to Abbas Tyabji, 4 August 1928; and letter to Raihana Tyabji, 3o January 1934 .

${ }^{26}$ Letter to Raihana Tyabji, 12 July $1927, C W M G O$. For an example of a published extract, see 'Position of Women', Young India, 17 October 1929, CWMGO. 
Raihana affectionately, if unusually, as 'Raihana the Crazy' or, more conventionally, as 'beloved daughter', and often finished his letters with 'a slap' if not 'a kiss'. ${ }^{27}$

It is perhaps no wonder then that Raihana was inspired to become, in her own words, one of 'Bapu's brahmachari soldiers' ${ }^{28}$ Reflected here was her decision not to marry, but instead to live according to Gandhi's principles while serving the nationalist cause. According to family sources, her commitment to celibacy was made after a possible engagement to a first cousin was broken, perhaps on account of her father's concerns about the medical effects of intermarriage within families (discussed in more detail below) or perhaps on account of her skin condition, a pigment deficiency known as leucoderma, that took the form of white patches all over her body. ${ }^{29}$ Interestingly, this medical condition gave Raihana an aura of exceptionalism that led one Tyabji descendant, quite approvingly, to describe her as 'more than normal': one who 'knew so much more than we do' ${ }^{30}$ Yet Raihana's poor health often left her bedridden and sometimes in need of medical intervention (including an operation on her displaced nasal septum in 1930). ${ }^{31}$ Her body's fragility thus interfered with her 'public work' at least until the early 1930s-a cause of great frustration, if Gandhi's letters to her on the subject are anything to go by. ${ }^{32}$ Still, she was responsible for acting as president of the Youth League (or Yuvak Sangh) in Baroda in the late $1920 s,{ }^{33}$ picketing liquor shops and fasting against foreign cloth merchants during the Civil Disobedience Movement of the early 1930 s, ${ }^{34}$ and serving as a trustee of the Kasturba Gandhi National Memorial Trust in the mid

${ }^{27}$ See, as examples, letters to Raihana Tyabji, 25 January 1931, 1 October 1932, 23 January 1933 and 14 August 1941, CWMGO.

${ }_{28}$ Mehta, Mahatma, p. 211.

${ }^{29}$ Mark Devereux, 'The Early Tyabji Women' from Retroblog of Najm Tyabji (I93O+): http://nstyabji.wordpress.com/2008/12/o7/the-early-tyabji-women/ [Accessed 15 October 2012 ]; and interview with Salima Tyabji, New Delhi, 3 February 2006.

${ }^{30}$ Interview with Rafia Abdul Ali, Bombay, 16 December 2005.

${ }^{31}$ See, as examples, letters to Raihana Tyabji, 29 December 1930 and 25 April $1945, C W M G O$.

${ }^{32}$ See, as an example, letter to Raihana Tyabji, 2o June 1932, CWMGO.

${ }^{33}$ Letter to Raihana Tyabji, 10 October 1928, CWMGO; Thakkar and Mehta, Understanding Gandhi, p. 204.

${ }^{34}$ Letters to Raihana Tyabji, 11 April 1930 and 25 January 1931; Draft Letter to Viceroy, 27 April 1930; and 'What Should One Not Do?', Navajivan, 1 March 1931, CWMGO; Thakkar and Mehta, Understanding Gandhi, p. 202. 
1940s. ${ }^{35}$ During the Quit India movement, she was even imprisoned on at least two occasions for participating in banned processions. ${ }^{36}$ Hence, Gandhi was inspired to write of her in Navajivan: 'Raihana, poor cripple, spends her days and nights thinking of India only. ${ }^{37}$ To Raihana herself, he opined: 'What a strange girl you are! You fall ill, return home, go out again to work and again fall ill. What wonderful enthusiasm [for] the cause!'38

Though generally resident at her parents' home in Baroda (where she appears to have written The Heart of a Gopi), Raihana often visited Gandhi's ashram at Sevagram and, a year after her mother's death in 1940, settled at Wardha with two of Gandhi's other disciples, D. B. Kalelkar (popularly known as Kakasaheb) and Sarojini Nanavati (shortened to Saroj). Raihana seems to have met the latter, the daughter of Judge D. D. Nanavati, while doing some sort of work at the Oriental Research Institute in Pune in 1932, and the two had soon become inseparable. ${ }^{39}$ As Gandhi wrote to Saroj 14 years later, 'May your devotion to service go on increasing and Raihana's with yours, or yours with Raihana's. You may be separate in body, but are not you one in spirit?'. ${ }^{40}$ In Wardha, Raihana also became very involved alongside Kalelkar in an organization to advance Hindustani as a national language for India, the Hindustani Prachar Sabha. ${ }^{41}$ This cause was perhaps surprising in the light of her earlier preference for English, Urdu and even Gujarati-and all the more so because Gandhi's letters and articles on the subject indicate that Raihana was 'rigidly' in favour of Hindustani being written in the Nagari script only (rather than the Urdu script as well). Apparently, she felt that the latter encouraged a 'separatist tendency' among Indian Muslims. ${ }^{42}$ After independence, Raihana, Saroj and Kalelkar relocated to a house in Gandhi's ashram in Delhi from where Raihana dedicated her latter years to offering spiritual guidance as comfort to those with mental

${ }^{35}$ Draft of Power-of-Attorney, 1 April 1945, CWMGO.

${ }^{36}$ Thakkar and Mehta, Understanding Gandhi, p. 172, $183,237$.

37 'The Spirit of Raas', Navajivan, 27 April 1930, CWMGO.

${ }^{38}$ Letter to Raihana Tyabji, 25 January 1931, CWMGO.

${ }^{39}$ Letter to Raihana Tyabji, 28 June 1932, CWMGO.

${ }^{40}$ Letter to Saroj Nanavati, 1 October 1946, CWMGO.

${ }^{41}$ Proceedings of the Hindustani Prachar Sabha Meeting, Wardha, 16 February 1946, CWMGO.

42 'Hindustani Written in Nagari Only', Harijan, 9 November 1947; and letter to Raihana Tyabji, 30 November 1947, CWMGO. 
difficulties. ${ }^{43}$ Part of the service, it seems, was to recount the past incarnations of visitors as she 'saw' them. ${ }^{44}$

In the context of Gandhian mythology, the Muslim-born Raihana is attributed with having taught Urdu to the Mahatma and for having encouraged him to incorporate verses from the Qur'an into his prayer meetings-two contributions that are well-documented in Gandhi's Collected Works. ${ }^{45}$ Feminist scholars also sometimes point to the way in which Raihana influenced Gandhi's writings on women's rights. ${ }^{46}$ In a piece in Young India from 1929, to take just one example of the evidence, Gandhi quoted a long passage from one of Raihana's letters in which, in the context of debates over the Sarda Act (or Child Marriage Restraint Act of 1929), she expressed her support for raising the minimum age of marriage for girls to 18 (rather than 14) and asserted women's rights to inheritance. ${ }^{47}$ What Raihana is best remembered for, however, is the bhajans, or devotional songs associated with the Bhakti movement, that she sang at the commencement of meetings at the ashram or on tour with Gandhi and even at annual sessions of the Congress. ${ }^{48}$ On this account, many around Raihana apparently considered her to be a 'reincarnation of the legendary Mirabai', a reference to the sixteenth century songstress and Krishna devotee that will also resonate with contemporary readers. ${ }^{49}$ Gandhi's love of Raihana's singing is recorded in many of his letters to her. As he wrote to her from jail in 1932, 'The bhajan you have sent will seem good only when I can hear it sung, and that can be when you come and

${ }^{43}$ For two separate accounts of these spiritual services offered by Raihana in her later years, see Devereux, 'Early Tyabji Women'; and Mehta, Mahatma, p. 3.

${ }^{44}$ See 'letters concerning past incarnations' from Raihana Tyabji to Mary Cushing Niles, 1954-71, in Niles Family Papers, RG 5/ 267, Friends Historical Library of Swarthmore College, Pennsylvania: http:/www.swarthmore.edu/library/ friends/ead/ $\mathbf{5}^{26} 6$ nile.xml [Accessed 15 October 2012].

${ }^{45}$ For an example of the secondary literature, see Gandhiji's Associates in India: http://www.gandhi-manibhavan.org/gandhicomesalive/comesalive_associates india.htm\#Tyabji,\%2oRaihana [Accessed 15 October 2012]. On Raihana's Urdū lessons and the Qur'an at prayer meetings, see, as examples, letter to Devdas Gandhi, 11 May 1932; and 'Speech at Prayer Meeting', Sodepur, 8 December 1945, CWMGO.

${ }^{46}$ Thakkar and Mehta, Understanding Gandhi, p. 40.

47 'Position of Women', Young India, 17 October 1929, CWMGO.

48 One particularly memorable performance at the Ahmedabad session of Congress in 1921 was recalled in Anil Nauriya's obituary of Raihana's sister, Sohaila Habib, 'Memories of another Gujarat': http://www.hinduonnet.com/2002/1 2/24/ stories/2002 122400941 ooo.htm [Accessed 15 October 2012]

${ }^{49}$ Yasmin Lukmani, 'The role played by the Tyabji women in the National Movement' in Nawaz B. Mody (ed.), Women in India's Freedom Struggle (Mumbai: Allied, 2000), pp. 219-236. The page quoted here is p. 227. 
sing it to me'. ${ }^{50}$ It is perhaps not surprising then that Raihana, along with her father Abbas and niece Hamida, was one of the chosen few permitted by Gandhi to see him in jail-his explanation being that they were 'like blood relations to me'. ${ }^{51}$

More racy accounts of Gandhi and Raihana highlight their shared interest in Tantric practices. This sexual fixation was alluded to by Raihana herself when, in her interview with Ved Mehta, she referred to brahmacharya experiments (which involved sleeping naked with members of the opposite sex) that later inspired Gandhi's own. ${ }^{52}$ This strange juxtaposition of eroticism and celibacy is something that emerges in Gandhi's correspondence with Raihana as well. On one occasion, he referred to her as a 'stranger to sensuous passion'. ${ }^{53}$ And yet, on another, he offered sympathy in response to a letter in which she had clearly unburdened herself about the difficulties of 'discipline'before admitting that he too was not 'too pure for sex-consciousness'. ${ }^{54}$ Much later in life, Raihana explained in her interview with Blum that she had come not to accept the principle of brahmacharya as practiced by Gandhi. 'Abstinence in an army', she explained 'was a necessity', but 'abstinence must not be made the rule of life for everybody'. Their point of departure seemed to be Gandhi's insistence on celibacy within marriage - an idea that, in her opinion, contradicted the 'sacredness of the marital relationship'. From her experience of watching others, she had come to believe that a man who practiced abstinence would become a 'sadist': someone who would be 'violent on the mental or emotional plane'. ${ }^{55}$

Accounts of Gandhi's closest associates thus cannot avoid mentioning Raihana. In characterizing her religious allegiances and identities, however, the depictions are varied. Sometimes she is recognized as a 'devout Krishna bhakt', or devotee, though 'born in a Muslim family'. ${ }^{56}$ Elsewhere, she is described as a 'devout Muslim', but

${ }^{50}$ Letter to Raihana Tyabji, 4 April 1932, CWMGO.

${ }^{51}$ Letter to R. V. Martin, Yeravda Mandir, 8 July 1930, CWMGO.

${ }^{52}$ Mehta, Mahatma, p. 5. For just one example of the former, see Nicholas F. Gier, 'Was Gandhi a Tantric?': http://www.class.uidaho.edu/ngier/gandtantric.htm [Accessed 15 October 2012].

${ }^{53}$ Letter to Abbas Tyabji, 12 September 1934, CWMGO.

${ }^{54}$ Letter to Raihana Tyabji, 18 June 1931, CWMGO.

55 Thakkar and Mehta, Understanding Gandhi, pp. $175^{-1} 7^{6}$

56 'Gandhiji's Associates in India': http://www.gandhi-manibhavan.org/ gandhicomesalive/comesalive_associates_india.htm\#Tyabji,\%2oRaihana [Accessed 15 October 2012]. 
'with respect for all religions'. ${ }^{57}$ Ved Mehta, on the other hand, opens his section on her in the oft-quoted Mahatma Gandhi and His Apostles with: 'By birth and upbringing she is a Sufi Muslim, and by inclination and choice a Vishnuite Hindu. ${ }^{58}$ In many ways, these divergent descriptions reflect Gandhi's own attempts to account for his disciple before different audiences. To a Muslim challenger questioning his inclusion of Qur'anic passages in prayer meetings at the height of communal conflict in January 1947, Raihana, as the instigator of the practice, was a 'devoted Muslim with a religious mind'. ${ }^{59}$ In a speech to Muslim women in Patna less than two months later though, she was 'a devotee of Krishna' who 'reads the Gita and the Koran together': a model for 'girls' to give up 'distinctions of caste and creed'. ${ }^{60}$ To Raihana herself and her father Abbas, her spiritual practices were referred to as those of a 'mystic' who should be left to '[sing] away in praise of Allah the Good and the Benevolent' ${ }^{61}$ On other occasions, Gandhi referred to her as a 'reader of the Gita', and noted her correspondence with the Bengali musician, Dilip Kumar Roy, on theories 'about Krishna'. ${ }^{62}$

In contrast, contemporary Tyabjis now tend to depict her as a Sufi, or at least 'influenced by Sufism', seemingly in an attempt to contain her unusual religious beliefs and activities within the Muslim fold ${ }^{63}$ This characterization resonates with Raihana's own account of her spiritual practice in her interview with Blum in 1973 in which she asserted:

The Sufi is quite different from the Mussalman. I am Sufi. I don't call myself Mussalman because I don't believe in and do not belong to the Mussalman sect. But I am Islamic, in that I accept whole-heartedly the blessed tenets of Islam, and the way that I live my way of living, is that of a Muslim monastery. ${ }^{64}$

And yet, earlier in the same interview, she had accounted for differences with Gandhi over the importance of ahimsa, or non-violence,

${ }^{57}$ V. Ramamurthy, Mahatma Gandhi: The Last 2ooDays (Chennai: The Hindu, 2003), p. 41 .

${ }^{58}$ Mehta, Mahatma, p. 207.

${ }^{59}$ Speech at Prayer Meeting, 29January 1947, CWMGO.

${ }^{60}$ Advice to Muslim Women, Patna, 16 March 1947, CWMGO.

${ }^{61}$ Letter to Raihana Tyabji, 5 September 1934; and letter to Abbas Tyabji, 20 September 1934, CWMGO.

${ }^{62}$ Letter to Raihana Tyabji, 19 December 1927; and letter to Dilip Kumar Roy, 17 June 1936, CWMGO.

${ }_{63}$ Interview with Rafia Abdul Ali, Bombay, 16 December 2005; Interview with Salima Tyabji, Delhi, 3 February 2006; Basu, Abbas, p. 21.

${ }^{64}$ Thakkar and Mehta, Understanding Gandhi, p. 217. 
in terms of her preference for a 'middle path': one that was 'both of the Gita and of the Koran' ${ }^{65}$ On other occasions, the balance swung in the opposite direction in that she portrayed herself as ' $80 \%$ Hindu', 'though born a Muslim', on account of believing in karma and samsara, or the cycle of birth and rebirth. ${ }^{66}$ This representation rings true with comments made during her interview with Mehta (carried out not long before her death) during which she made a number of references to his and her 'previous incarnations' ${ }^{67}$ In that she also described Lord Krishna appearing and speaking to her (even in the course of the interview), one may assume that-however her religious identity was constructed by her and others-the passion aroused in the course of 'writing' The Heart of a Gopi in the 1920 s did not leave her. ${ }^{68}$ What this recourse to bhakti reveals in terms of self-representation will be explored in the following section.

\section{The recourse to bhakti}

According to Raihana, she had no role in crafting the story that came through her hand. As she specified from the outset with the certainty of any life writer depicting their outpouring as 'truth-telling', 'the truth is that this story is not mine except in that it has been written by this hand.' She went on: 'During the three days that it took to write I had a distinct sensation of being possessed by something from outside myself and of being compelled to write even in spite of myself' ${ }^{69}$ Her abdication of responsibility for writing smacks of a 'convention of passivity' within the long tradition of writing life stories and journeys with Islam by which no suitably modest author should really be seen to be writing on his or her own initiative. ${ }^{70}$ Barbara Metcalf has pointed to this phenomenon with reference to the hajj narrative of Pakistani novelist, Mumtaz Mufti. He records that he wrote about 'what happened in Mecca', though 'not knowing

${ }^{65}$ Ibid., p. 179 .

${ }^{66}$ Basu, Abbas, p. 20.

${ }^{67}$ Mehta, Mahatma, p. 209.

${ }^{68}$ Ibid., p. 211.

${ }^{69}$ Tyabji, Heart, p. vi. Bold type in the original.

70 Barbara D. Metcalf, 'What Happened in Mecca: Mumtaz Mufti's "Labbaik"' in Robert Folkenflik (ed.), The Culture of Autobiography: Constructions of Self-Representation (Stanford: Stanford University Press, 1993), pp. 149-167. The quote here comes from p. 157 . 
what happened', because 'God grabbed him'. ${ }^{71}$ In this context, we may debate how far it is appropriate to speak of choice per se in the form of the story that Raihana told. Perhaps it is better to treat it simply as part of that corpus of Islamic literature concerned with dreams and visions, revelation and prophecy. ${ }^{72}$ And yet, within the religious context in which she was writing, her recourse to the bhakti traditionso often associated with a rejection of religious authorities and the false spirituality in which their rituals could trap the pious individualin itself seems highly revelatory of a liminal self caught between increasingly monolithic conceptions of 'Hinduness' and 'Muslimness'.

Of course, to seek a more personalized relationship with God by depicting oneself as a female lover in relation to the divine, as Raihana does in The Heart of a Gopi, is not exclusive to the bhakti tradition. In devotional poetry and music associated with Sufi Islam, whether sufiana-kalam, qawalli or the ghazal-the poetic voice is often indeterminate or female, addressing a beloved representative of the divine that may also be of indeterminate gender or identifiably male or even female. ${ }^{73}$ There is even a story-though not substantiated by Urdu or Persian sources-of the fourteenth century poet, Amir Khusrau, posing as a female lover before his pir, Shaikh Nizamuddin Auliya, apparently during the Hindu spring festival of colour, Holi. ${ }^{74}$ The trope is one of longing to be united with the cruel and fickle lover from whom the devotee experiences painful separation. Here we may quote a line from early in Raihana's text to draw a parallel: 'That Krishna seems to be a wonderful being! Who he is, what he does, where he lives, where he is now, all this [is] a complete mystery...this Krishna, is he, too, full of colour, full of light, full of music? Ah, one day I shall know' ${ }^{75}$ Yet, as the last line suggests, whereas the highest aspiration of the devotee within Sufic literature is to suffer in the face of the beloved's indifference, the gopi does not, ultimately, remain apart from her God. Worth noting here too is that, while Raihana

${ }^{71}$ Metcalf, 'What Happened in Mecca', p. $15^{8-1} 59$.

72 On this sub-genre of Islamic literature, see Kate Brittlebank, 'Piety and Power: A Preliminary Analysis of Tipu Sultan's Dreams' in her edited volume, Tall Tales and True: India, Historiography and British Imperial Imaginings (Victoria: Monash University Press, 2008), pp. 31-41. My thanks to Andrea Major for this reference.

${ }^{73}$ On the female voice in the Sufi tradition, see Shemeem Burney Abbas, The Female Voice in Sufi Ritual: Devotional Practices in India and Pakistan (Austin, Texas: University of Texas Press, 2003).

${ }^{74}$ My thanks to Sunil Sharma for this anecdote.

${ }^{75}$ Tyabji, Heart, pp. 10-1 1 . 
demonstrated a thorough knowledge of the ghazal tradition in her letters to Gandhi-often sending him favoured lyrics (for instance, by Bahadur Shah 'Zafar') in Urdu or Gujarati translation ${ }^{76}$ —it was bhajans that, as noted previously, she chose to write and sing herself. Raihana thus laid claim to a place within the bhakti tradition in an act that may itself be read as self-representation.

It has been noted already that, by birth, Raihana was a Sulaimani Bohra, a denomination of especial relevance in this context. The Bohras were a sect of Ismaili Shiism originally established in Yemen, but who probably came to Gujarat in western India at some point in the thirteenth century. Over the centuries that followed, the community experienced innumerable schisms with the Sulaimani branch to which the Tyabjis belonged recognizing the leadership of a different $d a^{\prime} i$, or spiritual leader, than others such as the Daudi Bohras or the Jafari Bohras. ${ }^{77}$ In Crossing the Threshold, Dominique-Sila Khan has explored the way in which Ismaili Islam in Gujarat especially represented an 'intricate interface' between supposedly separate and even antagonistic religious groupings in South Asia as represented by the labels, 'Hinduism' and 'Islam'. ${ }^{78}$ The ongoing openness of Sulaimani Bohras to a range of different religious practices, even at a time of growing communitarianism and intolerance, is evident from those customs and attitudes recorded in the goodly stash of autobiographical writings produced by different Tyabjis in the twentieth century. ${ }^{79}$ Raihana herself wrote in her later book of reminiscences, Suniye Kakasahib ${ }^{80}$, of the 'inter-communal culture' within her childhood home in Baroda by which the family 'celebrated Diwali, Dussehra, Holi, Bhai duj, Nagpanchami, Utran (the kite festival), Muharram, Id, Papeti (the Parsi New Year) and Christmas with equal

${ }^{76}$ See, as an example, letter to Raihana Tyabji, 7 July 1932.

${ }^{77}$ For a brief introduction to the Bohras, see Ira M. Lapidus, A History of Islamic Societies, $2^{\text {nd }}$ edn. (Cambridge: Cambridge University Press, 2002), p. 377. For a more comprehensive study, see Asghar Ali Engineer, The Bohras (New Delhi: Vikas, 1980).

${ }^{78}$ Khan, Crossing the Threshold.

${ }^{79}$ For just one example, see my discussion of Atiya Fyzee's 'openness, or at least curiosity, to other religious faiths' in her Zamana-i-tahsil in Siobhan Lambert-Hurley and Sunil Sharma, Atiya's Journeys: A Muslim Woman from Colonial Bombay to Edwardian Britain (Delhi: Oxford University Press, 2010), Chapter 4.

${ }^{80}$ R. Tyabji, Suniye Kakasahib (Wardha: Hindustani Pracher Sabhai, 1954), quoted in Basu, Abbas. 
enthusiasm'. ${ }^{81}$ Of her father, Gandhi wrote too: 'His Islam had room for all the great religions of the earth'. ${ }^{82}$

Nevertheless, by the time of Raihana's birth in 1901, the Tyabjis as a family group were, as Khan terms it, 'creating orthodoxies' ${ }^{83}$-in the sense that they were seeking to prove their Islamic credentials in a number of different ways. One method was the jettisoning of the clan's mother tongue of Gujarati for the north Indian lingua franca of Urdu by family decree in $1859 .{ }^{84}$ Another was through the establishment or patronage of Islamic organizations associated with a broader movement of socio-religious reform-a prominent example being the Anjuman-i-Islam founded in Bombay in $1876 .{ }^{85}$ Yet another method was intermarriage with more 'mainstream' Muslims, whether Sunni or Shia, from other parts of the Indian subcontinent. Raihana's two older sisters, Shareefa and Sohela, for instance, were married, not to cousins within the clan as was the usual Tyabji practice, but instead to Hameed Ali, an officer in the Indian Civil Service, and Muhammad Habib, a university professor at Aligarh Muslim University. ${ }^{86}$ According to Theodore Wright Jr, these marriages were less to do with hypergamy than exogamy after Abbas Tyabji read a book on the 'undesirable and inheritable physical traits' that could result from 'too much inbreeding' within a family. ${ }^{87}$ Still, when combined with 'Urduization' and reformism, these marriages (and many others besides) had the effect of tying the Tyabjis much more closely to what Wright calls, the 'old Mughal ruling class' ${ }^{88}$ _in other words, making them more identifiably 'Muslim'.

And yet, for all these efforts, there is no doubt that Raihana's birth community still retained a liminal status within South Asia's complex religious landscape during her lifetime. As evidence we may consider

${ }^{81}$ Basu, Abbas, p. 41 .

${ }^{82}$ Basu, Abbas, p. 78.

${ }^{83}$ Khan, Crossing the Threshold, Chaper 3.

${ }^{84}$ On the Tyabji clan's adoption of Urdu, see Marlen Karlitzky, 'The Tyabji ClanUrdu as a Symbol of Group Identity', Annual of Urdu Studies, vol. 17 (2002); Theodore P. Wright, Jr's 'Muslim Kinship and Modernization: The Tyabji Clan of Bombay' in Imtiaz Ahmad (ed.), Family, Kinship and Marriage among Muslims in India, Delhi: Manohar, 1976), pp. 217-238, especially p. 227; and Lambert-Hurley and Sharma, Atiya's Journeys, Chapter 1.

85 On this organization, see Gail Minault, Secluded Scholars: Women's Education and Muslim Social Reform in Colonial India (Delhi: Oxford University Press, 1998), pp. 182192.

${ }^{86}$ Basu, Abbas, pp. 20-2 1.

87 Wright, 'Muslim Kinship and Modernization', p. 229.

${ }^{88}$ Ibid., p. 227. 
an incident recorded in her Suniye Kakasahib in connection with her father. Apparently, having found the Jama Masjid in Baroda to be in a poor state of repair, Abbas Tyabji decided to collect donations for it to be renovated, perhaps sometime in the 1890 s, in part from the Muslim community and in part by securing a grant from the maharaja. And yet, when the mosque was renewed, he was excluded from entry. As Raihana records: 'On the first Friday after the inauguration of the mosque, when babajan [her father] together with some Sulemaini Bohras went to offer namaz, the Sunnis said, "You cannot offer namaz here. You are not Muslims." They drove them out with lathis' (sticks). ${ }^{89}$ Even as Abbas asserted his Islamic credentials with a great act of piety, so he and his community were denied a place in the Muslim fold. Raihana's disgust at her father's treatment, and by extension the organized and dominant forms of Islam represented by the 'Sunnis' at the mosque, is plain from her response to this incident: 'What shameful behaviour to make such distinctions in the House of God!'. ${ }^{90}$

In the light of this past, both communitarian and familial, Raihana's recourse to bhakti as a means to tell her story makes much more sense. The very form and practice allowed her to legitimize a sense of self that was, not just at odds with increasingly rigid definitions of religious identity, but actually embraced the inclusivity that had been at the heart of the Sulaimani Bohra community and her own family's practice, at least until very recently. Of course, it is important to recognize that the Bhakti movement too was undergoing a process of solidification and sedentarization in this period. ${ }^{91}$ An effect of this new orthodoxy, in a point of especial relevance for the next section, was that bhakti was increasingly purged of its eroticism-to the point that the nineteenth century Bengali mystic, Ramakrishna, though willing to dress up as a woman to replicate being a gopi before Krishna (a practice known as madhura bhava), often equated sex with defecation. ${ }^{92}$ Still, for the Muslim-born Raihana, bhakti's connotation, even more than that of Sufism, must have been that of a rejection of a formulaic and exclusionary paradigm in favour of a celebration of her inherited

${ }^{89}$ Basu, Abbas, p. $3^{6-37 .}$

${ }^{90}$ Ibid., p. 37 .

${ }^{91}$ On this process, see Peter Van der Veer, Gods on Earth: The Management of Religious Experience and Identity in a North Indian Pilgrimage Centre (Delhi: Oxford University Press, 1989); and Sumit Sarkar, 'Kaliyuga, Chakri and Bhakti: Ramakrishna and His Times' in his Writing Social History (Delhi: Oxford University Press, 1997), pp. 282-357. My thanks to Oliver Godsmark for raising this point during my seminar in Leeds.

${ }^{92}$ Sarkar, 'Kaliyuga', p. 313. 
and inherent liminality. How and why she then used the gopi tradition specifically to tell her particular story will be explored in the following section.

\section{Using the gopi tradition}

Those familiar with the Islamic context will know that it boasts a long tradition of recording life stories quite apart from the Western biographical and autobiographical tradition. From the time of the Prophet Muhammad himself, 'narrations' of an exemplary lifewhether scholar, saint, poet or king-were used to didactic purpose: as a model for 'ordinary' Muslims. Distinctive to this literary heritage were a number of specific features, not least a humoral understanding of personality, a lack of chronology, an attention to moral lessons, a rejection of individual agency and an emphasis on relationships with others. ${ }^{93}$ Until the nineteenth century it was rare for women to participate in the genre, but not entirely unheard of. ${ }^{94}$ The onslaught of colonialism accompanied by the introduction of print culture to the Indian subcontinent was still, however, transformative on Muslims writing lives. It inspired, in Francis Robinson's words, a 'growth of self-consciousness and reflective habit' among South Asian Muslims, male and female, represented in one form at least by a proliferation of life-writing. ${ }^{95}$ Increasingly, Muslims from all walks of life wrote more and different autobiographies in which the emphasis was less on the 'Perfect Man' of the Sufi tradition (to borrow Robinson's formulation once again) and more on the 'perfect person': 'the manifold nature of the human individual' or, more simply put, the self. ${ }^{96}$

The Tyabji clan offers an excellent case in point, starting with the dynasty's founder. Having established himself as a prosperous cotton merchant in a Bombay flourishing under East India Company

${ }^{93}$ This summary is based on Barbara D. Metcalf, 'The Past in the Present: Instruction, Pleasure and Blessing in Maulana Muhammad Zakariyya's Aap Biitii' in Arnold and Blackburn, Telling Lives in India, pp. 116-143. Relevant pages are pp. 119-121.

${ }^{94}$ For a South Asian example, see Ruby Lal's discussion of Gulbadan Begam's Humayun-nama in Domesticity and Power in the Early Mughal World (Cambridge: Cambridge University Press, 2005).

${ }^{95}$ Francis Robinson, Islam and Muslim History in South Asia (Delhi: Oxford University Press, 200o), pp. 95, 115 .

${ }_{96}$ Robinson, Islam, p. 95. 
rule, Tyab Ali recorded his 'rags to riches' story in an autobiography that offered important inspiration to his many descendants. ${ }^{97}$ Subsequently, an inordinate number of individual Tyabjis narrated their lives, or fragments of them, in memoirs, autobiographies and travel accounts that date from the nineteenth century to the present. ${ }^{98}$ Among them were a significant number of women. Two out of three daughters of the first generation of the Fyzee branch of the clan, to take a representative example, published full-length travelogues-or, more properly, travel diaries (roznamchah) - in which they recounted their journeys, physical and metaphorical, to Britain, Europe and West Asia in the Edwardian era. ${ }^{99}$ The clan's various branches also kept unusual family diaries, known as Akhbar ki Kitab (or 'news-books'), in which public and private events, quotidian and otherwise, were recorded. Women especially were urged to contribute, and thus it is not surprising that it was here that Raihana's mother, Ameena, wrote a short account of her life that was later published in a prominent women's magazine. ${ }^{100}$ Her father, Abbas, too kept a personal diary in which he recorded earlier incidents revelatory of his adult self. ${ }^{101}$

For Raihana then there was no shortage of autobiographical models close at hand. Hers was not so much a problem, as Malhotra writes of Peero living in nineteenth century Punjab, of finding a way to write about her life in a 'society unfamiliar with the self-absorption required of an autobiography'. ${ }^{102}$ And yet, for her first foray into public selfrepresentation-if we may interpret it as that-Raihana explicitly chose not to write a memoir, nor even a travelogue. Instead, she elected, like many women before her, to employ a familiar narrative form-in this case, the devotional mode of bhakti associated with the gopi tradition-as a means of writing about her feelings and experiences. We might draw a parallel here with the way in which

${ }^{97}$ Ali, Asaf A. A. (ed.), 'The Autobiography of Tyabji Bhoymeeah', Journal of Asiatic Society of Bombay (New Series), vol. $3^{6-7}(1961-2)$.

${ }^{98}$ For a well-known example by a male Tyabji, see Badruddin Tyabji, Memoirs of an Egoist, 2 vols (New Delhi: Roli Books, 1988).

${ }_{99}$ Nazli Rafia Sultan Nawab Begam Sahiba, Sair-i-Yurop (Lahore: Union Steam Press, n.d.); and Atiya Fyzee, Zamana-i-tahsil (Agra: Matba' Mufid-i-'Am, 1921). For a translation and commentary on the latter, see Lambert-Hurley and Sharma, Atiya's Journeys.

100 'A Page from the Past: Extracts from the Diary of Amina Binte Badruddin Tyabji', Roshni (Delhi), Special number 1946, pp. 69-73.

${ }^{101}$ Abbas Tyabji's diaries are now preserved in the Nehru Memorial Museum and Library.

102 Malhotra, 'Telling Her Tale?', p. 555. 
women throughout South Asian history have used epic, including the Ramayana, and the afflicted Sita especially, to narrate their own suffering. ${ }^{103}$ This narrative strategy could be interpreted as a means of drawing a metaphorical veil over women's voices-not meant to be heard in the South Asian context-while, at the same time, endowing their individual experiences with a kind of validity not achievable otherwise. Where then may we find Raihana's 'self' in her little book of bhakti devotionalism so firmly located with the gopi tradition? And what was she trying to relate that she could not say otherwise? What did the gopi tradition offer specifically that other readily available models of life-writing did not?

As a starting point, it is important to note that, in many ways, The Heart of a Gopi follows conventional, even formulaic, patterns. Great importance is invested in the devotee, Raihana's alter-ego Sharmila, gaining a vision of the deity, a darshan that cannot help but fill her with 'nameless ecstasy'. ${ }^{104}$ As she exults in the latter stages of the narrative, 'before my eyes that incarnation of divine beauty began to shine with greater and with greater brilliance, until there stood before me a Form made, from head to foot, purely of dazzling blue light.... ${ }^{105}$ There is also that 'literal and realistic interaction', to borrow Snell's phrase, between the devotee and the deity himself. ${ }^{106}$ Sharmila, like the best of gopis, spends her days frolicking with the other milkmaids and the child Krishna, partaking in his pranks, revelling in his mischief. ${ }^{107}$ She is driven into a frenzy by the sound of his 'Celestial Flute', loses her earrings (if, notably, not her sari) in this state of 'madness', and even allows her husband's supper to be pilfered while in a state of having 'lost all consciousness of self'. ${ }^{108}$ Her sister-inlaw, representing society's censure of a married woman disregarding 'normal social roles', chastises her for her impropriety-for following Radha and the other 'vile' gopis into forgetting 'their vows and their

${ }^{103}$ My thanks to Veena Oldenburg for encouraging me to draw out this point. It has been developed in: Velcheru N. Rao, 'A Ramayan of their Own: Women's Oral Tradition in Telegu' in Paula Richman (ed.), Many Ramayanas: The Diversity of a Tradition in South Asia (Berkeley: University of California Press, 1991), pp. 114-136.

${ }^{104}$ Tyabji, Heart, p. 57.

105 Ibid.

106 Snell, 'Raskhān', p. 32 .

107 See the section entitled 'Two weeks later' in Tyabji, Heart, pp. 62-69.

108 Tyabji, Heart, pp. 30, 47, 53. For comparison with the early gopi tradition, see David Kinsley, Hindu Goddesses: Visions of the Divine Feminine in the Hindu Religious Tradition (Berkeley: University of California Press, 1988), pp. ${ }_{3}-85$. 
Pati Vrata' by chasing after Krishna. ${ }^{109}$ And yet, ultimately, it is those moments in which Sharmila's earthly soul submits to Krishna's grace that represent, as one would expect, the pinnacle of the narrative. 'The world hath been flung off like a soiled garment, I am clad in the shining robes of Bhakti, pure white, gleaming as a white pigeon's wing in sunlight!. . .I come, my lord, I come!'. ${ }^{110}$

To find self-representation then one must look beyond the convention outlined here to the level of emphasis and innovation within this particular telling of the gopi story. We may ask: in what ways, however subtle, does Raihana's account diverge from the gopi formula? Is there a sense in which Sharmila is not the average gopi? If so, in what ways and in which contexts? And what do these ways and contexts tell us about Raihana's decision to use the gopi tradition to narrate her own story, her own self? Did the gopi tradition open up avenues for self-representation and perhaps even self-fulfilment not achievable otherwise? To begin answering these questions, let us take two examples of distinctive themes within the narrative-one relating to social status and the other to erotic mysticism-that help illustrate the way in which the self may be revealed in this type of text, and also the reasons why.

The first theme that stands out as distinct in Raihana's telling of the gopi story relates to the leaving behind of social status. Unlike your usual milkmaid, Sharmila is located from the outset in social terms as a 'rich man's beloved daughter' who has been married off hurriedly to a Gauli, a keeper of cattle, seemingly to protect her from the 'wrath of the King'. ${ }^{111}$ Whereas yesterday she was 'clad in silk', today only a 'red rag conceals [her] nakedness'. ${ }^{112}$ She sleeps on the floor of a poor man's hut when used to a palace, milks cows with the other maidens when accustomed only to picking flowers, waits on the 'father, mother, sisters' of her low-caste husband rather than issuing commands. ${ }^{113}$ She is 'abased, humbled to the dust'. ${ }^{114}$ The resonance with Raihana's own experience of staying in Gandhi's ashram seems pronounced when set against her later account of arriving there with her own personal commode. Displayed 'royally' on top of her luggage,

\footnotetext{
109 Tyabji, Heart, p. 24.

${ }^{110}$ Ibid., pp. $5^{1-2}$.

111 Ibid., pp. 1-2

112 Ibid., p. 1.

113 Ibid., pp. 1-2.

${ }^{114}$ Ibid., p. 19.
} 
it announced to all others that she, from her privileged background among Bombay's elite—a 'spoilt girl', as Gandhi characterized her in $1932^{115}$ — was incapable of 'squatting over a trench latrine without a proper seat'. 'You can imagine how silly I felt', she told Ved Mehta, 'how chastened'. And yet 'because of Bapu', Raihana went on to explain, 'I-like Sharmila enchanted by Krishna-learned to go anywhere, sleep anyplace, eat anything. ${ }^{116}$ Her autonomous self, we come to see, takes form when removed from the social context.

In this connection, it is also worth noting that Raihana's decision to become a disciple of Gandhi was not uncontested. Though members of the Tyabji clan are often celebrated now for their early and consistent espousal of Gandhian ideals, ${ }^{117}$ we see from Gandhi's Collected Works that Raihana often found herself in conflict with her parents, Abbas and Ameena Tyabji, over her chosen path. Throughout the late 1920 s and early 1930s, she wrote lengthy epistles-sadly, not preserved, though they are referred to in Gandhi's own correspondence-in which she complained bitterly that they would not allow her, in Gandhi's words, 'to wear whatever you like and to see or be seen by any friends you like'. ${ }^{118}$ Indicated here is not a young woman's tempestuous assertion of false independence, but rather a political statement in favour of spurning 'Western facilities and contrivances' in favour of wearing khadi, or clothes made of homespun cloth, and meeting fellow nationalists of different castes, classes and religions. ${ }^{119}$ In response, Gandhi advised Raihana not to oppose her parents openly-not least because they were 'rulers of the household' on whom she depended for her 'maintenance-but rather to 'convince everybody around you of the justice of your action' through 'gentle suggestions'. ${ }^{120}$ The Heart of a Gopi may have fulfilled that very function in a suitably oblique fashion.

A second theme emphasized in Raihana's narrative is the expression of love of the divine through the love of an individual. Despite being chastised by her sister-in-law, Sharmila ultimately convinces her alarmed husband and in-laws that her love of Krishna, though expressed in highly eroticized, earthly terms, is acceptable on the

115 Letter to Dr Mohammad Alam, 26 November 1932, CWMGO.

116 Mehta, Mahatma, pp. $210-211$.

${ }^{117}$ Lukmani, 'The role played by the Tyabji women in the National Movement', pp. $219-236$.

${ }^{118}$ Letter to Raihana Tyabji, 12 July 1927, CWMGO.

${ }^{119}$ Letter to Raihana Tyabji, 14 and $19 \mathrm{July} 1927$, and 5 March 1930, CWMGO.

${ }^{120}$ Letter to Raihana Tyabji, 12 July 1927 , and 19 October 1929, CWMGO. 
basis that the love of a God and the love of a man may actually be complementary. As Sharmila describes her attraction to her husband:

It is not thy body that I love, it is thy soul, and all the goodness, and sweetness, and strength thereof. I love thee for thy strong manhood; for thy virtue; for thy intellect; thy skill, thy tenderness; for thy simplicity, truth and steadfastness. All of this, yea, every single one of these qualities, is Krishna! All, all is Krishna! All is Krishna! ${ }^{121}$

The gopi tradition is, of course, by nature playful and erotic (regardless of what Ramakrishna made of it). But the connection between the intense passions described in The Heart of a Gopi and Raihana's own sexual experimentation, as referred to in the earlier section, seems plain. Consider another quote from her later interview with Mehta: 'I often told Bapu that there was a great difference between repressing libido and outgrowing it, and that the only way to outgrow it was to give free rein to it-to indulge it and satiate it'. ${ }^{122}$ This, she explains, is what she had done in previous incarnations-to the point that even her skin condition was attributed to 'recklessly indulging my sexual appetite'. ${ }^{123}$ In alluding to Mehta's own sexual conquests in a previous life, she also grouped herself with other 'passionate, romantic girls'. ${ }^{124}$ Though a brahmachari, Raihana's self is revealed as sexual.

This second theme especially suggests why the young Raihana may have chosen bhakti and the gopi tradition specifically as a means of self-representation, rather than participating more explicitly in the autobiographical tradition of her clan or Islamic societies more generally-namely, it allowed her to circumvent prohibited expressions of female sexuality. Contrary to popular perception, Muslim women in South Asia have written autobiographically about their sexual relations in the modern period. We might consider, as just one early example, Nawab Shah Jahan Begam's encyclopaedic manual for women, Tahzib un-Niswan wa Tarbiyat ul-Insan, first published in 1889. Here, she used her own experiences with her first and second husbands as illustration in a passage on women's right to carnal pleasure. ${ }^{125}$ Indicated by this example is that it was primarily in a princely context that sexual matters were broached by female

121 Tyabji, Heart, p. 61.

${ }^{122}$ Mehta, Mahatma, p. 211.

123 Ibid., p. 209.

${ }^{124}$ Ibid., p. 211.

125 Shah Jahan Begam, Tahzib un-Niswan wa Tarbiyat ul-Insan (Women's Reform, or the Cultivation of Humanity) (Delhi: Matba'i-Ansari, 1889). 
memoirists-perhaps on account of the authors' more elite status, a more developed zenana culture or the relative autonomy of 'native states'. ${ }^{126}$ In reformist circles like those frequented by the Tyabjis, autobiographical references to sexual matters were much scarcer, most probably reflecting the greater influence of Victorian notions of bourgeois sexuality. Certainly Raihana's female cousins who wrote life histories in a more conventional way were highly modest in their approach-Atiya Fyzee not even alluding to her reputed affair with the poet Iqbal, nor Nazli, the Begam of Janjira, to the problems in her marriage, in their respective European travelogues. ${ }^{27}$

For Raihana The Heart of a Gopi seems to have offered a means of justifying her unconventional lifestyle-her leaving behind of the comforts associated with the Tyabji's social status to live as a brahmachari in one of Gandhi's ashrams-while, at the same time, allowing her to speak of a mystical path expressed through earthly passion. By juxtaposing her individual telling of the gopi story against later accounts of her own life, the seeming contradictions of a brahmachari experimenting with Tantric practices and writing in bhakti's amorous mode are brought into sharp relief, but also, in a way, resolved. We are given a sense of the innate tensions and even conflict that must have played out in Raihana's mind, if not her body, between her innate desire for sexual indulgence and her vow of celibacy: a sexualized self that she dare not articulate in a more unambiguously autobiographical form. And yet, just as she writes so convincingly of love without ever making explicit any amorous physical encounter between Sharmila and Krishna, so the gopi persona seemed to offer her an erotic outlet without consummation. Krishna-or may we read Gandhi?_-is Raihana/Sharmila's salve: the promise of spiritual fulfilment expressed as human desire, but without the actual indulgence. We may recall here the quote from the second section in which Raihana identified Gandhi not just as parent and teacher, but also as companion and child. Appropriately then, at the end of her tale, Sharmila is finally reunited with her husband, in-laws, parents and sister in expressing a common devotion to Krishna. Together, their hearts 'thrilling with love', they sing, 'Jaya Krishna! Jaya, Jaya

\footnotetext{
${ }^{126}$ I have developed this point as part of a separate paper on intimacy and sexuality in Muslim autobiographical writing in South Asia, forthcoming.

${ }^{127}$ Atiya, Zamana-i-Tahsil; and Nazli, Sair-i-Yurop. For an analysis of these silences, see Lambert-Hurley and Sharma, Atiya's Journeys, Chapter 2; and Delight and Disgust: Gendered Encounters in the Travelogues of the Fyzee Sisters' in On the Wonders of Land and Sea: Persianate Travel Writing, eds. R. Micallef and Sunil Sharma, forthcoming.
} 
Krishna!'128 This mysticism is considered as a form of autobiography to conclude.

\section{The marvellous and the miraculous: conclusion}

I first read The Heart of a Gopi in the personal collection of Salima Tyabji, herself a descendant of Tyab Ali, at her home in Delhi. The copy that she generously allowed me to peruse at her kitchen table (while, memorably, drinking the most delicious cinnamon tea) had, apparently, been presented by Raihana herself to Salima's father, Saif. In the back was a handwritten note, perhaps attributable to this Cambridge-educated lawyer, then mathematician. 'The only element I personally dislike', it read, 'is that miraculous touches have been used. But it is a habitual device with mystics and bhaktas of all times and creeds. Some get so fond of the marvellous and the miraculous they make it the dominant note in all they say or sing. ${ }^{129}$ This most eloquent scribble sums up, effectively, what might be the expected response to this text from one rooted in a Western rational tradition. How could Raihana have written this text, and yet not? Does she seriously expect us to believe that she was 'possessed' for three days during which she wrote things that even she 'could not understand'? How could she have been transformed into a gopi living in Vrindavan at the feet of Krishna? Raihana herself recognized these likely misgivings in her introduction to the text when she wrote: 'I must risk being either smiled or sniffed at by "rationalists" if I am to speak the truth here'. ${ }^{130}$

As a trained historian, it would be easy for me, too, to dismiss The Heart of a Gopi as little more than a wild and creative tale by a slightly barmy woman. And yet, whatever we may think of it, Raihana believed it happened. In that way, it becomes a very personal tale of her mystical experience, not so very different from those highly individualized accounts written by Muslims on hajj, for instance, in the modern period. We may think again here of Mumtaz Mufti. Though a self-proclaimed 'nominal Muslim' laying claim to a cosmopolitan intellectual inheritance, he experienced all sorts of 'strange things' in the course of his pilgrimage to Mecca-from

128 Tyabji, Heart, p. 74 .

${ }^{129}$ Ibid., inside back cover.

${ }^{130}$ Ibid., p.vi 
dreams indicating the future to idols (or bat) in the Ka'aba. ${ }^{131}$ Metcalf points out that this 'expanded sense of reality' is only to be expected from a text rooted in the long Urdu-Persianate tradition of writing autobiography and biography. ${ }^{132}$ Here, as she writes, 'the definition of what is presented as part of life's experience is very inclusive. Put differently, magic is on the loose'. ${ }^{133}$ We may consider, as just one other example, the haij narrative of one of South Asia's greatest Islamic scholars, Shah Waliullah Dihlawi-'in no sense a travelogue but rather a compendium of visions and dreams'. ${ }^{134}$ Approached from this perspective, Raihana's little book of bhakti devotionalism-mediated through a long tradition of Islamic life-writing-becomes as valid to those interested in self-representation as any other more identifiably autobiographical text.

The Heart of a Gopi then requires us to rethink what we actually mean by autobiographical writing. Standard definitions of autobiography elaborated by literary theorists in the context of a Euro-American tradition have tended to celebrate the Enlightenment ideal of the autonomous individual crafting his own life story-for the hero is usually male-into a coherent, retrospective narrative as a function of personality. ${ }^{135}$ The historical contingency and gendered representation inherent to these definitions have encouraged a number of post-modern and post-colonial theorists to jettison the term 'autobiography' in favour of other monikers considered more accepting of temporal and geographical diversity. ${ }^{136}$ Often preferred in the South Asian context in that, in this mode, it is deemed more inclusive of the heterogeneity of autobiographical practice is the term 'life history'. As Arnold and Blackburn write in the introduction to their important Telling Lives in India, they choose to employ 'life histories' to apply to their collection on the basis that it does not 'privilege print

131 Metcalf, 'What Happened in Mecca', p. 149.

132 Ibid., p. 154 .

133 Ibid., p. $15^{2}$.

${ }^{134}$ Ibid.

135 Consider, as an example, Philippe Lejeune's definition, often considered definitive even as his own work has belied it: 'We call autobiography the retrospective narrative in prose that someone makes of his own existence when he puts the principal accent upon his life, especially upon the story of his own personality'. Translated from his L'autobiographie en France (1971) in Robert Folkenflick (ed.), The Culture of Autobiography: Constructions of Self-Representation (Stanford: Stanford University Press, 1993), p. 13 .

${ }^{136}$ Sidonie Smith and Julia Watson, A Guide for Interpreting Life Narratives: Reading Autobiography (Minneapolis: University of Minnesota Press, 2010, $2^{\text {nd }}$ edn.), p. 3 . 
over orality', nor does it 'ignore the often fragmentary or allusive nature of many life-historical forms'. ${ }^{137}$ 'Fragmentary' and 'allusive' are two descriptors that may rightly be applied to The Heart of a Gopi too. And yet, if we hope to disrupt the established Western canon of autobiography in order to imagine what Smith and Watson refer to as a 'new, globalized history of the field'138 —as this paper and the wider project to which it belongs hope to do ${ }^{139}$-it seems only appropriate to employ the term that has resonance on a global scale as well. In the end, I would assert that we can read Raihana Tyabji's bhakti devotionalism as self-representation and even, to take the point further, as a form of autobiography, if only an autobiography of the imagination. The adjective autobiographical is thus appropriated as an inclusive holdall for a wide range of self-referential writing-even 'the marvellous and the miraculous'.

So what can we say of the self represented here? Raihana Tyabji is best known to history as a devotee of Gandhi, rather than for her writing or even her singing. But standard narratives of the Mahatma's followers or associates rarely get beyond a brief and rather confused attempt to explain her unusual status as a Muslim-born Krishna bhakt. In this circumstance, The Heart of a Gopi provides access to the inner self - the 'soul', as Raihana terms it in her introduction-of this particular gopi. Her recourse to the bhakti tradition itself is revelatory of her experience of growing up with her family's Islamic ambitions, but still ambiguous status as Sulaimani Bohras within South Asia's colourful religious spectrum. Here is a woman, her chosen genre says, who will not be trapped by religious authority or ritual or conventioneven to the point of stepping outside her 'Muslimness'. Yet it is the points of disjuncture with more conventional gopi narrativeswhether in terms of emphasis or innovation-that offer the best insights into this liminal self. Only by using the metaphorical language of bhakti can Raihana explain her rejection of social hierarchy, but acceptance of a mystical path expressed through earthly passion. A creative reading of this miraculous account then allows a woman's resistant voice to be recovered.

137 Arnold and Blackburn, Telling Lives in India, p. 9.

138 Smith and Watson, Guide for Interpreting Life Narratives, p. 5 .

${ }^{139}$ I speak here of my individual research project on autobiographical writing by Muslim women in South Asia, as well as the international research network to which I belong on 'Women's Autobiography in Islamic Societies' (see http://www.waiis.org [accessed 15 October 2012]). 